\title{
The Effect of Intellectual Capital and Board Characteristics on Value Creation and Growth
}

\author{
Mahdi Salehi ${ }^{1, *(1)}$ and Grzegorz Zimon ${ }^{2, *(D)}$ \\ 1 Department of Economics and Administrative Sciences, Ferdowsi University of Mashhad, \\ Mashhad 9177948974, Iran \\ 2 Department of Finance, Banking and Accountancy, The Faculty of Management, \\ Rzeszow University of Technology, 35-959 Rzeszow, Poland \\ * Correspondence: mehdi.salehi@um.ac.ir (M.S.); gzimon@prz.edu.pl (G.Z.)
}

Citation: Salehi, M.; Zimon, G.

The Effect of Intellectual Capital and Board Characteristics on Value Creation and Growth. Sustainability 2021, 13, 7436. https://doi.org/ $10.3390 /$ su13137436

Academic Editor: Michele Grimaldi

Received: 18 May 2021

Accepted: 23 June 2021

Published: 2 July 2021

Publisher's Note: MDPI stays neutral with regard to jurisdictional claims in published maps and institutional affiliations.

Copyright: (c) 2021 by the authors. Licensee MDPI, Basel, Switzerland. This article is an open access article distributed under the terms and conditions of the Creative Commons Attribution (CC BY) license (https:// creativecommons.org/licenses/by/ $4.0 /)$.

\begin{abstract}
The present study evaluates the relationship between intellectual capital and corporate board characteristics on value creation and growth. Different work experiences and education were two indexes of intellectual capital, and gender diversity was the only characteristic of board members. The study's statistical population includes companies listed on the Tehran Stock Exchange during 2012-2018. Panel data regression models were employed to elucidate the relationship between research variables. The obtained results indicated that the intellectual capital of the board members of companies listed on the Tehran Stock Exchange does not affect companies' value and growth. According to the results, appointing female managers should not be dependent on firm growth because gender diversity does not affect the value creation and growth of companies listed on the Tehran Stock Exchange.
\end{abstract}

Keywords: value creation; firm growth; intellectual capital; gender diversity

\section{Introduction}

Firm value relies considerably on intellectual capital [1]. As a reliable source of sustainable competitive advantage, intellectual capital can lead a firm to economic growth and technological development. Based on the available propositions, a sustainable competitive advantage is a measure providing companies and enterprises with the opportunity of developing and maintaining some distinctive advantages on the market. To be more precise, in the current knowledge-based economy, such competitive advantages are achievable only by those companies understanding the value of applicable resources of the 21st-century consist of information, knowledge, creativity, innovation, and more importantly, intellectual capital, as the fundamental source of others. For instance, combining the available tangible resources inside a company, such as fixed assets and inventories, with its intangible assets, similar to employing expert opinions, in a distinctive and novel manner may supply that company with an advantageous competitive position on the market, in which this competitive advantage beside efficient use of resources is the key factor for a thriving macroeconomic and financial performance [2]. In other words, the existence of a company in the competitive market significantly contingents upon its available resources, discriminating it from its potential competitors [3], which in turn may lead to firm growth and value creation. In this paper, the terms "growth" and "value creation" are defined as two proxies reflecting effective firm performance.

Considering the different aspects of resource application and the combination of available resources such as tangible and intangible assets by decision-makers, it might be tough to appoint a proxy showing the outcome of optimal usage of resources by authorities [4]. In this regard, there is a long-lasting debate between accounting scholars, in which some believe that accounting-based metrics are more applicable by virtue of conformity [5], in contrast, others believe that market-based metrics, including the stock 
return, MVA (market value added) and EVA (economic value added) are more efficient to measure a given firm's performance since these metrics include other aspects of a firm outcome, such as efficient use of intangible assets, that are not classified and disclosed on the financial figures. Therefore, since the explanatory variables of this study are not among the reported items on financial statements, the authors have chosen market-based measures as response variables.

As the mainstream of intangible assets, it is expected that the application of intellectual capital plays a critical role in developing sustainable competitive advantages for companies.

Presently, intellectual capital is a vital intangible asset to a business, especially in high-tech industries [6]. A considerable part of organizational knowledge is embodied in the board's intellectual capital, contributing significantly to the board's decision-making. The board's intellectual capital should be managed appropriately to create value for a company even in unpredictable economies, increase competitive advantages, and stabilize profitability [6]. The board of directors is the best tool for developing and managing corporate intellectual capital, affecting company growth [7]. Decision-making theories have positive effects on team diversity and innovation [8], in which the "team diversity" is explained in this paper as an aggregate team-level formation representing differences among members of an interdependent group considering the specific personal attributes of the members [9]. In particular, diversity is defined as how the board members are heterogeneous, respecting their demographics features. According to the Upper Echelon Theory, diversity among the board members will help them have more innovation, formulate more effective strategies, and make higher quality decisions, resulting in higher quality actions and value creation. It is believed that intellectual capital management calls for innovation, perception, and more flexibility in the decision-making process. Such characteristics are more obvious in the boards with more diversity [7]. By board characteristics, we usually mean one of the concepts of the number of board members, CEO (Chief Executive Officer) duality, board independence, etc. [10-12]. While in some other resources, the board characteristics mean the demographic features, which is defined as particular characteristics of individual members, including gender, age, occupational tenure, educational background, and experience (like Carter et al., 2010; Díaz-Fernández et al., 2015), in this research, we mean the latter. The significance of the board's demographic characteristics is that much important that Carter et al. [13] believed that such characteristic is one of the most critical governance issues about managers and shareholders in modern corporate issues, gender, race, and the cultural composition the board members. The board composition is also another critical factor in corporate governance, where the aim is to define some structures to converge the interests of shareholders and managers [14]. According to the facts mentioned above, the present study aims to assess how the intellectual capital and the board characteristics contribute to the value creation and growth of companies listed on the Tehran Stock Exchange.

The rest of the paper is organized as follows. In the next section, the theoretical background and existing literature are argued. Then, in Section 3, the methodology and statistical models are presented and discussed. Next, in the result section, findings and the way of their observation are presented. Finally, in the fifth section, the authors discuss and conclude the finding.

\section{Literature Review}

\subsection{Firm Improvement and Intellectual Capital}

Intellectual capital is a set of structural and human capital, including the applied business, organizational technology, customer relationship, and professional skills. Producing a sense of competitive advantage could lead to a company's growth in the market [15]. Intellectual capital is a type of asset, which measures the capability of an organization for generating wealth. It is also argued that such an asset has no objective and physical nature and is a type of an intangible asset, which is achieved by applying properties related to human resources, organizational performance, and relations outside the organizations [16]. 
Finally, it is defined that Intellectual capital refers to the intellectual assets from a strategic and global perspective.

Cabrita and Jorge [17] argue that, from a strategic perspective, intellectual capital is used to create and apply knowledge to enhance firm value. Value creation is at the heart of strategic management, and the rationale of intellectual capital is its ability to create value. Thus, intellectual capital and strategy are intricately woven. Cruz Basso et al. [16] demonstrate that all proposed intellectual capital characteristics may lead to intra-organizational growth. Intellectual capital can be defined as a combination of intangible or trivial assets, which are not disclosed in the balance sheet. According to accounting literature, human capital, organizational capital, relational capital, and customer capital are among the specific characteristics and components of intellectual capital [18-20]. If the intellectual capital characteristics are being managed properly, companies' growth could lead to companies' growth [21].

Alternatively, several studies suggest that intellectual capital is positively related to a firm's financial performance and market value. They may be considered an allocator of future financial performance [22-24]. For instance, Dženopoljac et al. [24] reveal that intellectual capital impacts the ICT industry's financial performance. Even it is suggested that intellectual capital may improve the bankruptcy models, which is pivotal to nowadays economy for wealth creation $[15,25,26]$. Bchini [1] found a positive and significant relationship between the components of intellectual capital and value creation. Vomberg et al. [27] discovered a complicated relationship between intellectual capital and brand value. The board's intellectual capital should be managed appropriately to create value for the company, increase the competitive advantages, and stabilize the profitability, especially in unpredictable economies [6]. Lu and Zhang [28] noted that the higher education of a CEO could increase the value of Chinese companies significantly.

In today's economy, which is based on knowledge and awareness of companies' future trends and the process of value creation, an essential element of planning is the intellectual capital of managers that are an indispensable part of firm value creation [29]. Hence, to improve production, managers must make the fixed price of goods and services, diligent and timely decisions to preserve the favorable quality. It is also suggested that increasing education plays an important role in gaining professional expertise, enhancing directors' cognitive skills. Therefore, it is expected that more educated directors may realize, analyze business matters more easily and propose more sufficient solutions.

Harjoto et al. [30] find that board nationality diversity and educational background diversity are positively associated with CSP. Salehi et al. [31] show that the audit committee's expertise, proxied by its' members' educational background, plays a significant role in improving its profitability. Salehi and Farzaneh [32] found that firms benefit from board human capital in terms of outside directors' proficiency, validity, experience, specialty, and knowledge to monitor and counsel managers. Polsiri and Sitthipongpanich [33] noted that those CEOs with related work experience had made better strategic decisions and subsequently raised the firm value.

Beattie and Smith [34] indicated that intellectual capital could significantly contribute to value creation and competitive advantage. Del Carmen Triana et al. [35] show that CEO educational background diversity positively impacts strategic change, ultimately improving firm performance. Olayinka et al. [36] emphasize the relevance of financial education for board members in improving firms' performance. Altuwaijri and Kalyanaraman [37] show that graduated CEOs contribute to firms' performance more significantly than less educated ones. Saidu's [38] findings indicate that CEO education improves a firm's profitability. Naseem et al. [39] find that CEO characteristics like age, gender, and education significantly affect firm financial decisions and firm performance. Lari Dashtbayaz et al. [40] show a positive relationship between board independence and human capital. However, they found a negative and significant link between audit committee size and human capital. 
In contrast, Schmidt suggests that educational levels or board gender quotas do not affect the positive relationship between board gender diversity and firm performance [41]. In addition, Elmagrhi et al. [42] do not show any evidence suggesting that the level of education of female directors impacts environmental performance. Therefore, we expect that boards with educated members in industry-related fields.

Prior literature also suggests that the greater educational level of directors plays a positive role in firm performance improvement and may cause improvement the innovation and a better understanding of customer's needs, which in turn improve efficiency and competitiveness [7,43]. One of the precursors to better managerial effectiveness is the attainment of some level of education. Education is an important tool for consideration in the employees' promotion and perhaps the remuneration. A good level of education has significance in raising the managers' prestige hence enabling them to give out an optimum decision

Darmadi et al. [44] evidence that board members' educational qualifications and the CEO matter, to a particular extent, explain either ROA or Tobin's $Q$. Doms et al. [45] indicate that more educated entrepreneurs tend to be located in metropolitan areas with more educated workforces. Moreover, highly educated areas have above-average entrepreneurship rates. Storey [46] recognizes that there is evidence that "high-performance work practices" appear to be associated with better performance but argues that this relationship is less likely to be present in middle-sized companies. Magoutas et al. [43] found that staff intellectual capital, proxied with academic certificate level, significantly affects companies' growth rate. However, Lu and Zhang [28] analyzed COE education's effect on the firm growth rate. Their findings indicated that the CEO's higher education has no significant impact on Chinese companies' growth rate.

Sansone et al. show that university investments positively impact the local community through the spin-off system, both in economic terms and intellectual capital. In the long term, these investments can enrich scientific humus and entrepreneurial mindsets [47]. La Torre et al. [18] suggest that losing confidentiality, integrity, or data availability because of a data security breach poses a threat to IC and value creation. Thus, cyberthreats compromise the social value of Big Data, impacting stakeholders' and society's interests. Cenciarelli et al. [19] show that intellectual capital performance is negatively associated with default probability. The findings also indicate that the bankruptcy prediction models that include intellectual capital have a superior predictive ability over the standard models. Salehi [20] propose that board members' higher educational levels may also decrease agency costs.

Considering the above discussion, two variables comprising educational background and level are separately proxied to examine the effect of intellectual capital on firm performance measured through value creation and firm growth. Therefore, the following hypotheses are presented:

Hypothesis $\mathbf{1}\left(\mathbf{H}_{\mathbf{1}}\right)$. Possessing an educational background by the board of directors' members positively impacts value creation within companies.

Hypothesis $\mathbf{2}\left(\mathbf{H}_{\mathbf{2}} \mathbf{)}\right.$. Possessing an educational background by the board of directors' members positively impacts promoting growth within companies.

Hypothesis $\mathbf{3}\left(\mathbf{H}_{\mathbf{3}}\right)$. Possessing different educational levels by the board of directors' members positively impacts promoting growth within companies.

Hypothesis $\left.4 \mathbf{(} \mathbf{H}_{\mathbf{4}}\right)$. Possessing different educational levels by the board of directors' members positively impacts value creation within companies. 


\subsection{Gender Diversity and Value Creation}

The boards' main responsibility is monitoring and providing recommendations for managers to improve the firms' performance. It is suggested that (1) such a monitoring function (proposed by agency theory) may explain the influential role of gender diversity in corporate performance, (2) resource dependence and human capital are proposed as explanatory theories by the diversity brought to the board by female directors, and (3) behavioral-based theories might elaborate it through some various behavioral features of women directors compared to their men colleagues [48].

According to agency theory, female directors on a board may develop a wider range of perspectives in decision-making processes, leading to greater independence of the board and reducing agency costs. Consequently, it is expected that such a characteristic in the boards increases the value of companies. This theory is proposed by academic bodies as a critical issue when discussing the significant impact of gender diversity on companies' performance [49]. For instance, supporting agency theory, Adams and Ferreira [50] argue that female directors may supervise and control board activities. In addition, Solimene et al. [47] argue that since women are more educated in recent years, having graduated with M.A and $\mathrm{Ph} . \mathrm{D}$., they are greatly professional and well-experienced, making decisions on the boards of directors efficiently.

Similarly, the resource dependency theory considers female directors unique and valuable resources for boards; they are considered an essential link between the firms, the existing environment, and the external resources on which a company competes. In other words, having ties and contacts by female directors with internal and external environments is proposed to draw resources into the organization, leading to improved economic performance [51]. Alternatively, Anderson et al. [52] argue that female directors possess innovative ideas to compare to those of the old boys' club. The new abilities proposing by female directors to the board provide innovative perspectives and valuable recommendations to executive managers, leading efficient decisions making, greater innovation and creativity, and better information availability [53-55]. Pucheta-Martínez and Gallego-Álvarez's [56] board characteristics, such as board size, board independence, and female director, are positively associated with firm performance [56]. Loukil et al. [57] show that stock market liquidity is positively and significantly associated with women directors' presence. However, a contradictory argument implies to potential disadvantages of female directorship. In this part, it is suggested that the relationship between gender diversity and independence is questionable. Having discouraged managers' motivations, stricter monitoring policies might decline shareholder wealth and the deteriorating effect on the relationship between managers and the board [50]. Moreover, a lack of cohesiveness among the board members and tokenism can degrade interactions among individuals working as advise providers.

Previous studies explain that the proportion and age of female directors positively affect overall corporate environmental performance. The proportion and age of female directors also have a positive effect on the three individual environmental performance components, namely, environmental (a) strategy, (b) implementation, and (c) disclosure [42] Yang et al. [58] explain the main sources of biases in the existing literature on women directors' effects on firm performance and review methods to account for these biases. Their results imply a negative effect of mandated female representation on firm performance and firm risk [53]. Schmidt [41] finds a positive relationship between board gender diversity and firm performance.

Green and Homroy [59] demonstrate a robust positive effect of female board representation on firm performance. They also demonstrate economically meaningful positive effects on the performance of female representation on board committees. A positive effect of gender diversity on financial performance is also reported [60]. Bøhren and Staubo [61] find that the Norwegian gender quota was associated with increased board independence and reduced firm value, particularly for smaller firms, more eager for valuable advice from board members than monitoring [61]. A non-linear relationship, especially in grades 2 , 
between female institutional directors and firm value. By increasing the number of female institutional directors on the board, the firm value will initially magnify. However, after reaching a certain value, the firm value goes down [62].

However, Bennouri et al. [48] find that female directorship significantly increases ROA and ROE and significantly decreases Tobin's $Q$ as a market-based performance.

Having suggested ambiguous conclusions about the association between gender diversity in the board of directors by existing literature, for instance, positive results are revealed by several studies $[41,58,59]$, and many others state negative impact $[59,61-64]$ as well as insignificant relationship, motivate us to conduct such an investigation to provide a more clear picture of such an association $[12,14,64]$. Therefore, the following hypotheses are proposed:

Hypothesis $\mathbf{5}\left(\mathbf{H}_{\mathbf{5}}\right)$. Gender diversity in the board of directors' members positively impacts value creation within companies.

Hypothesis $\mathbf{6}\left(\mathbf{H}_{\mathbf{6}}\right)$. Gender diversity in the board of directors' members positively impacts promoting growth within companies.

\section{Research Method}

The statistical population of the study includes all companies listed on the stock exchange during 2012-2018. Using the systematic elimination method, the samples of the study were established based on the following criteria, which require the companies: (1) to be listed on the Tehran Stock Exchange before 2011; (2) to have financial year-end before March; (3) to present the information required for calculating research variables; (4) not to change their financial year-end during the terms of the study; and (5) not to be among investment, bank, and insurance companies. Having extracted and classified the required data, the 840 observations are analysed through panel-data models to test the hypotheses.

\subsection{Research Variables}

Two variables of growth and value creation are used in this study. First, the firm growth is calculated as follows: Equation (1)

$$
\text { Growth }=\frac{S_{t}-S_{t-1}}{S_{t-1}}
$$

$S$ is the company's amount of sales. Moreover, according to Wibowo and Barasategui (2008), to measure value creation, Market Value Added (MVA) is used as follows: Equation (2)

$$
M V A=M V E-B V E
$$

$M V E$ and $B E$ are the market value of equity and book value of equity, respectively, Mengi and Bhatia [65] market value added (2015), used respectively for calculating the value creation of Indian and Iranian companies.

Two variables of "the board characteristics" and "the board intellectual capital" were used as the independent variables. Three aspects of human, structural, and relational capital are usually used for intellectual capital. In this study, we are only concentrated on human capital. According to Díaz-Fernández et al. [6], the following variables are used as the board's intellectual capital. In this regard, Blau's criteria are employed to obtain the board diversities (educational background and level). Blau's criteria vary from zero (meaning no diversity) to the maximum of one (meaning full potential diversity among the appointed criteria). The variation between zero and one represents the fluctuation between lower and greater diversity. Accordingly, Blau's outcome has no negative values [66]. 
1. Educational background diversity (Edubackdiv): the following equation is used to measure educational background diversity: Equation (3)

$$
\text { Edubackdiv }=1-\sum_{i} P_{i}^{2}
$$

where $P_{i}$ the board member ratio in the $i$ th educational group, $i$ is the number of studies represented on the board. Given that "the Iranian guideline for the classification of educational levels and academic degrees" is used to identify the educational groups.

2. Educational level diversity (Edulevdiv): the following equation is used to measure the educational level diversity: Equation (4)

$$
\text { Edulevdiv }=1-\sum_{i} P_{i}^{2}
$$

where $P_{i}$ is the percentage of board members in each educational category, in line with previous papers, the maximum educational level of each board member is identified within five categories consist of "high school diploma or lower", "associate degree", "bachelor of science", "master of science", or "Ph.D. or higher".

In this study, the gender of the board members is used as the only demographic feature of the board of sample companies. In this case, we also calculate the gender diversity (Gendiv) of the sample companies' board members using the previous equation. Recently, gender diversity among the listed companies on the Tehran Stock Exchange has become more important.

According to Díaz-Fernández et al. [6] the followings are the control variables:

- Sizefirm: natural logarithm of total sales [6]

- Agefirm: the difference between the year the company established and the current year;

- Sizeboard: the board number.

\subsection{Models of Hypotheses Testing}

To test the research hypotheses, the following regression models were used: Hypothesis model 1

$$
M V A=a_{0}+b_{1} \text { Edubackdiv }+b_{2} \text { Sizefirm }+b_{3} \text { Agefirm }+b_{4} \text { Sizeboard }+e
$$

The above model Equation (5) is employed to examine Hypothesis 1, assessing the impact of educational background diversity of board members on the market value creation of listed companies.

Hypothesis model 2

$$
M V A=a_{0}+b_{1} \text { Edulevdiv }+b_{2} \text { Sizefirm }+b_{3} \text { Agefirm }+b_{4} \text { Sizeboard }+e
$$

The above model Equation (6) is employed to examine Hypothesis 2, assessing the impact of educational level diversity of board members on the market value creation of listed companies.

Hypothesis model 3

$$
\text { Growth }=a_{0}+b_{1} \text { Edubackdiv }+b_{2} \text { Sizefirm }+b_{3} \text { Agefirm }+b_{4} \text { Sizeboard }+e
$$

The above model Equation (7) is employed to examine Hypothesis 3, assessing the impact of educational background diversity of board members on the sale growth of listed companies.

Hypothesis model 4

$$
\text { Growth }=a_{0}+b_{1} \text { Edulevdiv }+b_{2} \text { Sizefirm }+b_{3} \text { Agefirm }+b_{4} \text { Sizeboard }+e
$$


The above model Equation (8) is employed to examine Hypothesis 4, assessing the impact of educational level diversity of board members on the sale growth of listed companies. Hypothesis model 5

$$
M V A=a_{0}+b_{1} \text { Gendiv }+b_{2} \text { Sizefirm }+b_{3} \text { Agefirm }+b_{4} \text { Sizeboard }+e
$$

The above model Equation (9) is employed to examine Hypothesis 5, assessing the impact of gender diversity of board members on the value creation of listed companies.

Hypothesis model 6

$$
\text { Growth }=a_{0}+b_{1} \text { Gendiv }+b_{2} \text { Sizefirm }+b_{3} \text { Agefirm }+b_{4} \text { Sizeboard }+e
$$

The above model Equation (10) is employed to examine Hypothesis 6, assessing the impact of gender diversity of board members on the sale growth of listed companies.

\section{Results}

The statistical indexes of the research hypotheses were reported in Table 1. According to the research results, the sample companies' sales growth is $19.3 \%$ on average, with a $41.7 \%$ standard deviation. As can be seen, the amount of income of the companies under study did not improve greatly. Indexes related to market value-added indicate that the sample companies' average market value is greater than their book value. This shows that the actual value of the sample companies is more than their registered and book value. Among the sample companies' board members, educational background (Edubackdiv) and education level (Edulevdiv) were not divergent. The highest educational level diversity among the sample year-companies is reported as 0.720 , and the highest education background diversity is equal to 0.800 . This occurs while the average amount of educational background/level diversity among the board members of companies under study is 0.480 and 0.460 , respectively. Moreover, the results of gender diversity, by the average amount of 0.035 and a standard deviation of 0.105 , reveal that the sample under study does not have that much gender diversity. According to the board size results, the smallest board among the companies under study has 3 members, and the largest one has 8 members, which belongs to Shiraz Petrochemical Company during 2012-2018. On average, the number of board members of the sample companies is 5.1 people, with a standard deviation of 0.44 people (Table 1 ).

\begin{tabular}{|c|c|c|c|c|c|c|}
\hline Variable & & Minimum & Median & Mean & Maximum & Standard Deviation \\
\hline Sales changes & Growth & -0.898 & 0.144 & 0.193 & 2.927 & 0.417 \\
\hline Market value-added & MVA & $-26,235,049$ & 359,854 & $3,610,720$ & $90,027,974$ & $11,103,173.048$ \\
\hline Educational background diversity & Edubackdiv & 0.000 & 0.480 & 0.480 & 0.800 & 0.174 \\
\hline Educational level diversity & Edulevdiv & 0.000 & 0.480 & 0.460 & 0.720 & 0.158 \\
\hline Gender diversity & Genderdiv & 0.000 & 0.000 & 0.035 & 0.480 & 0.105 \\
\hline Firm size & Sizefirm & 9.620 & 13.580 & 13.750 & 19.720 & 1.708 \\
\hline Firm age & Agefirm & 8.000 & 38.000 & 36.200 & 69.000 & 13.947 \\
\hline Board size & Sizeboard & 3.000 & 5.000 & 5.080 & 8.000 & 0.437 \\
\hline
\end{tabular}

Table 1. Descriptive indexes of the research variables.

In this section, the Shapiro-Wilk test is used to analyze the statistical distribution of the dependent variables. Table 2 displays the results of the test. Also, the skew and elongation coefficients of the dependent variables are presented. According to the results obtained from the Shapiro-Wilk test and achieved levels of significance, the normality hypothesis of no dependent variable (sales growth and market value-added) is accepted (Sig. < 0.05). The skew and elongation coefficients of these three variables report some facts. According to the skew coefficient, it is implied that the statistical distribution of the sales growth variable is more symmetrical than the market value added (the skew coefficient of these two variables is smaller). Additionally, by comparing the elongation coefficients, we could observe that the statistical distribution of market value added is more than that of the other 
variable. There are various strategies for the normality of the statistical distribution of a variable. One of the most appropriate strategies is the use of normalizer transformation. Johnson is one of the powerful transformations for normalizing the statistical distribution of a variable. To perform the process in the R setting, we could use the RE Johnson function. After performing the transformation, the Shapiro-Wilk test results show that the sales growth's normality's statistical distribution is accepted at a 0.05 level of error $(\mathrm{w}=0.997$, Sig. < 0.05). Moreover, the market value added variable's normality is approved at the 0.01 level of significance (Sig. > 0.01). Further, the Johnson transformation has improved the distribution features to a great extent and made them closer to the normal distribution's corresponding values (Table 2).

Table 2. The results of the Shapiro-Wilk test for evaluating the normality of dependent variables.

\begin{tabular}{lll}
\hline & Before Johnson Transformation & After Johnson Transformation \\
\hline Sales growth & & \\
Shapiro-Wilk (W) statistic & 0.890 & 0.997 \\
Shapiro-Wilk level of significance (Sig.) & 0.000 & 0.297 \\
Skew coefficient & 1.719 & 0.096 \\
Elongation coefficient & 10.662 & 2.864 \\
Market value-added & & \\
Shapiro-Wilk (W) statistic & 0.394 & 0.994 \\
Shapiro-Wilk level of significance (Sig.) & 0.000 & 0.015 \\
Skew coefficient & 4.488 & -0.005 \\
Elongation coefficient & 26.695 & 2.946 \\
\hline
\end{tabular}

The significance level of regression coefficients is $>0.05$.

One of the other basic assumptions of the regression models is no linearity among descriptive variables. In linearity, the regression coefficients will be estimated unrealistically, which could affect the hypothesis testing results. There are different solutions for this issue, one of the best of using the correlation matrix. Among the descriptive variables, Pearson and Spearman correlation coefficients are shown in Table 3. The biggest Pearson correlation coefficient is 0.193 between two variables of gender diversity and educational background diversity. Similarly, the biggest Spearman correlation coefficient is 0.218 between the above-said variables. All calculated correlation coefficients were small, in the range of $(-0.5$ and 0.5$)$, so no severe linearity problem is expected among descriptive variables.

Table 3. Pearson (below the primary diameter) and Spearman (above the main diameter) among the descriptive variables.

\begin{tabular}{lllllll}
\hline & $\begin{array}{l}\text { Educational } \\
\text { Background } \\
\text { Diversity }\end{array}$ & $\begin{array}{l}\text { Educational } \\
\text { Level } \\
\text { Diversity }\end{array}$ & $\begin{array}{l}\text { Gender } \\
\text { Diversity }\end{array}$ & $\begin{array}{l}\text { Firm } \\
\text { Size }\end{array}$ & $\begin{array}{l}\text { FIRM } \\
\text { AGE }\end{array}$ & $\begin{array}{l}\text { Board } \\
\text { Size }\end{array}$ \\
\hline Educational background diversity & 1.000 & 0.083 & 0.218 & 0.005 & 0.131 & 0.147 \\
Educational level diversity & 0.067 & 1.000 & -0.031 & -0.027 & 0.030 & 0.012 \\
Gender diversity & 0.193 & -0.109 & 1.000 & 0.121 & 0.136 & -0.052 \\
Firm size & 0.038 & 0.006 & -0.133 & 1.000 & -0.001 & 0.123 \\
Firm age & 0.083 & 0.047 & 0.143 & -0.023 & 1.000 & 0.026 \\
Board size & 0.099 & 0.019 & -0.058 & 0.079 & 0.017 & 1.000 \\
\hline
\end{tabular}

The significance level of regression coefficients is $>0.05$.

The F-Limer and Hausman tests were reported in Table 4 to decide the estimation method of every regression model. According to the results of these two tests, the fixed effects method was used for testing all research models, such that the results of the FLimer test about all models show that the assumption of the equality of sectional unit effects (companies) is rejected (Sig. < 0.05). Moreover, according to the Hausman test, the randomness of sectional unit effects is also rejected (Sig. $<0.05$ ), and all are considered fixed. 
Table 4. The results of the F-Limer and Hausman tests.

\begin{tabular}{|c|c|c|c|c|c|}
\hline \multirow[b]{2}{*}{ Hypothesis } & \multicolumn{2}{|l|}{ F-Limer Test } & \multicolumn{2}{|l|}{ Hausman Test } & \multirow[b]{2}{*}{$\begin{array}{l}\text { Model Estimation } \\
\text { Method }\end{array}$} \\
\hline & The Test Statistic (F) & $\begin{array}{l}\text { Level of } \\
\text { Significance (Sig.) }\end{array}$ & The Test Statistic $\left(X^{2}\right)$ & $\begin{array}{l}\text { Level of } \\
\text { Significance (Sig.) }\end{array}$ & \\
\hline 1 & 3.572 & 0.000 & 17.605 & 0.000 & Fixed effects \\
\hline 2 & 3.576 & 0.000 & 17.790 & 0.000 & Fixed effects \\
\hline 3 & 2.288 & 0.000 & 134.140 & 0.000 & Fixed effects \\
\hline 4 & 2.295 & 0.000 & 141.230 & 0.000 & Fixed effects \\
\hline 5 & 3.542 & 0.000 & 19.134 & 0.000 & Fixed effects \\
\hline 6 & 2.276 & 0.000 & 133.36 & 0.000 & Fixed effects \\
\hline
\end{tabular}

The significance level of regression coefficients is $>0.05$.

The result of hypothesis testing is as follows:

The results of Hypothesis 1 are displayed in Table 5 using the fixed effects method. However, given the significance level, the effect of education background diversity on value-added is not significant $(t=-0.174$, Sig. $<0.05)$. According to the model statistics, we could conclude that the existing descriptive variables in the model have elucidated about $4 \%$ of the dependent variable variance $\left(R^{2}=4.3 \%\right)$, and the estimated model is significant, generally $(\mathrm{F}=5.528$, Sig. $<0.05)$. On the other hand, the Durbin-Watson statistic indicates no serial correlation among the estimated model's residues $(1.5<\mathrm{DW}<2.5)$. Therefore, according to the results, there is no significant relationship between value creation and education background diversity, so the first hypothesis is rejected.

Table 5. The results of the first hypothesis testing.

\begin{tabular}{|c|c|c|c|c|}
\hline \multicolumn{5}{|c|}{$\begin{array}{l}\text { Statistical Model: } \\
M V A=a_{0}+b_{1} \text { Edubackdiv }+b_{2} \text { Sizefirm }+b_{3} \text { Agefirm }+b_{4} \text { Sizeboard }+e\end{array}$} \\
\hline Descriptive variable & Symbol & Regression coefficient & T statistic & Level of significance (Sig.) \\
\hline Educational background diversity & Edubackdiv & -0.045 & -0.174 & 0.862 \\
\hline Firm size & Sizefirm & 0.064 & 0.837 & 0.403 \\
\hline Firm age & Agefirm & 0.065 & 3.335 & 0.001 \\
\hline Board size & Sizeboard & -0.143 & -0.891 & 0.373 \\
\hline Coefficient of determination $\left(\mathrm{R}^{2}\right)$ & & 0.043 & & \\
\hline F statistic & & 5.528 & & \\
\hline F level of significance & & 0.000 & & \\
\hline Durbin-Watson statistic (DW) & & 1.892 & & \\
\hline
\end{tabular}

The significance level of regression coefficients is $>0.05$.

The results of Hypothesis 2 are displayed in Table 6 using the fixed effects method. However, given the significance level, the effect of education level diversity on valueadded is not significant $(t=-0.266$, Sig. $<0.05)$. According to the model statistics, we could conclude that the existing descriptive variables in the model have elucidated about $4 \%$ of the dependent variable variance $\left(\mathrm{R}^{2}=4.3 \%\right)$, and the estimated model is significant, generally $(\mathrm{F}=5.538$, Sig. $<0.05)$. On the other hand, the Durbin-Watson statistic indicates no serial correlation among the estimated model's residues $(1.5<\mathrm{DW}<2.5)$. Therefore, according to the results, there is no significant relationship between value creation and education level diversity, so the second hypothesis is rejected.

The results of Hypothesis 3 are displayed in Table 7 using the fixed effects method. However, given the significance level, the effect of education background diversity on firm growth is not significant $(t=-0.998$, Sig. $<0.05)$. According to the model statistics, we could conclude that the existing descriptive variables in the model have elucidated about $23 \%$ of the dependent variable variance $\left(R^{2}=22.6 \%\right)$, and the estimated model is significant, generally $(\mathrm{F}=36.140$, Sig. $<0.05)$. On the other hand, the Durbin-Watson statistic indicates no serial correlation among the estimated model's residues $(1.5<\mathrm{DW}<2.5)$. Therefore, according to the results, there is no significant relationship between firm growth and education background diversity, so the third hypothesis is rejected. 
Table 6. The results of the second hypothesis testing.

\begin{tabular}{lcccc}
\hline \multicolumn{2}{l}{ Statistical Model: } & & & \\
$M V A=a_{0}+b_{1}$ Edulevdiv $+b_{2}$ Sizefirm $+b_{3}$ Agefirm & $+b_{4}$ Sizeboard $+e$ & & Level of significance (Sig.) \\
\hline Descriptive variable & Symbol & Regression coefficient & T statistic & 0.790 \\
Educational level diversity & Edulevdiv & -0.068 & -0.226 & 0.416 \\
Firm size & Sizefirm & 0.062 & 0.814 & 0.001 \\
Firm age & Agefirm & 0.065 & -0.323 & 0.359 \\
Board size & Sizeboard & -0.147 & & \\
Coefficient of determination $\left(\mathrm{R}^{2}\right)$ & & 0.043 & & \\
F statistic & & 5.538 & & \\
F level of significance & & 0.000 & & \\
Durbin-Watson statistic $(\mathrm{DW})$ & & 1.891 & & \\
\hline
\end{tabular}

The significance level of regression coefficients is $>0.05$.

Table 7. The results of the third hypothesis testing.

\begin{tabular}{|c|c|c|c|c|}
\hline \multicolumn{5}{|c|}{$\begin{array}{l}\text { Statistical Model: } \\
\text { Growth }=a_{0}+b_{1} \text { Edubackdiv }+b_{2} \text { Sizefirm }+b_{3} \text { Agefirm }+b_{4} \text { Sizeboard }+e\end{array}$} \\
\hline Descriptive variable & Symbol & Regression coefficient & T statistic & Level of significance (Sig.) \\
\hline Educational background diversity & Edubackdiv & -0.336 & -0.998 & 0.319 \\
\hline Firm size & Sizefirm & 1.111 & 10.997 & 0.000 \\
\hline Firm age & Agefirm & -0.256 & -9.927 & 0.000 \\
\hline Board size & Sizeboard & 0.060 & 0.284 & 0.776 \\
\hline Coefficient of determination $\left(\mathrm{R}^{2}\right)$ & & 0.226 & & \\
\hline F statistic & & 36.140 & & \\
\hline F level of significance & & 0.000 & & \\
\hline Durbin-Watson statistic (DW) & & 1.899 & & \\
\hline
\end{tabular}

The significance level of regression coefficients is $>0.05$.

The results of Hypothesis 4 are displayed in Table 8 using the fixed effects method. However, given the significance level, the effect of education level diversity on firm growth is not significant $(t=1.323$, Sig. $<0.05)$. According to the model statistics, we could conclude that the existing descriptive variables in the model have elucidated about $23 \%$ of the dependent variable variance $\left(\mathrm{R}^{2}=22.7 \%\right)$, and the estimated model is significant, generally $(\mathrm{F}=36.384$, Sig. $<0.05)$. On the other hand, the Durbin-Watson statistic indicates no serial correlation among the estimated model's residues $(1.5<\mathrm{DW}<2.5)$. According to the results, there is no significant relationship between firm growth and education level diversity, so the fourth hypothesis is rejected.

Table 8. The results of the fourth hypothesis testing.

\begin{tabular}{|c|c|c|c|c|}
\hline \multicolumn{5}{|c|}{$\begin{array}{l}\text { Statistical Model: } \\
\text { Growth }=a_{0}+b_{1} \text { Edulevdiv }+b_{2} \text { Sizefirm }+b_{3} \text { Agefirm }+b_{4} \text { Sizeboard }+e\end{array}$} \\
\hline Descriptive variable & Symbol & Regression coefficient & T statistic & Level of significance (Sig.) \\
\hline Educational background diversity & Edulevdiv & -0.444 & -1.323 & 0.186 \\
\hline Firm size & Sizefirm & 1.096 & 10.911 & 0.000 \\
\hline Firm age & Agefirm & -0.259 & -10.031 & 0.000 \\
\hline Board size & Sizeboard & 0.029 & 0.136 & 0.892 \\
\hline Coefficient of determination $\left(\mathrm{R}^{2}\right)$ & & 0.227 & & \\
\hline F statistic & & 36.384 & & \\
\hline F level of significance & & 0.000 & & \\
\hline Durbin-Watson statistic (DW) & & 1.896 & & \\
\hline
\end{tabular}

The significance level of regression coefficients is $>0.05$.

The results of Hypothesis 5 are displayed in Table 9 using the fixed effects method. However, given the significance level, the effect of gender diversity on the market value added is not significant $(t=-0.509$, Sig. $<0.05)$. According to the model statistics, we 
could conclude that the existing descriptive variables in the model have elucidated about $4 \%$ of the dependent variable variance $\left(R^{2}=43 \%\right)$, and the estimated model is significant, generally $(\mathrm{F}=5.587$, Sig. $<0.05)$. On the other hand, the Durbin-Watson statistic indicates no serial correlation among the estimated model's residues $(1.5<\mathrm{DW}<2.5)$. According to the results, there is no significant relationship between the board characteristics and value creation, so the fifth hypothesis is rejected.

Table 9. The results of the fifth hypothesis testing.

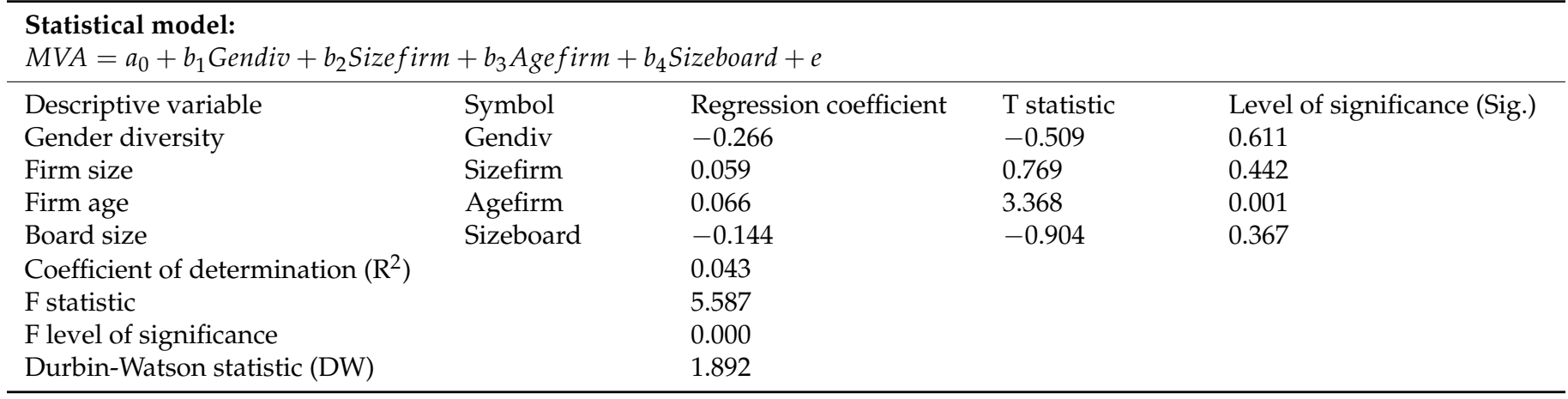

The significance level of regression coefficients is $>0.05$.

The results of Hypothesis 6 are displayed in Table 10 using the fixed effects method. However, given the significance level, the effect of gender diversity on sales growth is not significant $(\mathrm{t}=0.483, \mathrm{Sig} .<0.05)$. According to the model statistics, we could conclude that the existing descriptive variables in the model have elucidated about $22 \%$ of the dependent variable variance $\left(\mathrm{R}^{2}=22.4 \%\right)$, and the estimated model is significant, generally $(\mathrm{F}=35.895$, Sig. <0.05). On the other hand, the Durbin-Watson statistic indicates no serial correlation among the estimated model's residues $(1.5<\mathrm{DW}<2.5)$. According to the results, there is no significant relationship between the board characteristics and firm growth, so the sixth hypothesis is rejected.

Table 10. The results of the sixth hypothesis testing.

\begin{tabular}{|c|c|c|c|c|}
\hline \multicolumn{5}{|c|}{$\begin{array}{l}\text { Statistical Model: } \\
\text { Growth }=a_{0}+b_{1} \text { Gendiv }+b_{2} \text { Sizefirm }+b_{3} \text { Agefirm }+b_{4} \text { Sizeboard }+e\end{array}$} \\
\hline Descriptive variable & Symbol & Regression coefficient & T statistic & Level of significance (Sig.) \\
\hline Gender diversity & Gendiv & -0.332 & -0.483 & 0.629 \\
\hline Firm size & Sizefirm & 1.095 & 10.842 & 0.000 \\
\hline Firm age & Agefirm & -0.256 & -9.852 & 0.000 \\
\hline Board size & Sizeboard & 0.046 & 0.219 & 0.827 \\
\hline Coefficient of determination $\left(\mathrm{R}^{2}\right)$ & & 0.224 & & \\
\hline F statistic & & 35.895 & & \\
\hline F level of significance & & 0.000 & & \\
\hline Durbin-Watson statistic (DW) & & 1.903 & & \\
\hline
\end{tabular}

The significance level of regression coefficients is $>0.05$.

\section{Discussion and Conclusions}

For this study, two distinctive measures are implemented for our performance variable, which may provide a clearer picture. The underlying theory suggests that increasing education plays an ameliorating role in providing innovative and creative pieces of advice for managers, leading to companies' improved performance. Moreover, female directors' existence on the board may lead to an enhanced firm performance by coming up with a wider range of perspectives in decision-making processes.

According to the findings of the first set of hypotheses, comprising the first and second hypotheses, diversity of board members' education is not likely to improve the firms' 
performance. However, the underlying theory and previous papers, including [35-39], noticed that the existence of educated managers, with the fields of study related to the company's activity, has a positive and significant impact on firm value creation. This is by in-depth analyses, a wider range of knowledge in the firm's activity that educated boards' members possess.

According to the results of the third and fourth hypotheses, we also find that educational level diversity has no significant impact on value creation and firm growth. It denotes that top managers' educational level in Iran's business environment does not determine business success. However, previous findings [28,61], evidence a positive impact of highly educated managers on firms' performance.

Finally, we find that having female board members have no significant influence on companies' value creation and firm growth. However, the theory argues that providing a wider range of perspectives in decision-making processes may turn female board members into a better choice to promote the firm value. In line with theory, refs. [67-70] indicate that female-managed businesses have a significant effect on economic growth.

One of the potentialities for inconsistent findings of this paper, in comparison to previous outcomes, might come from the business environment of the Tehran stock exchange. For instance, CEO ability [71], auditor characteristics [15], and ownership structure [72] are among the effective factors on firm performance in the Iran market environment. Therefore exclusion of these explanatory variables may result in a different conclusion. In addition, one of the fundamental issues of Iran's educational system is following inefficient and unapplied-scientific procedures, especially in higher education levels. In this regard, scholars of educational efficiency argue that the higher education system of Iran is significantly suffering from the ineffectiveness of decisions and policies made by authorities and its non-reliance on scientific and empirical evidence [73]. In contrast, it is expected that the greater working experience of individual board members may play an allocative role in value creation and provision of growth opportunities [32].

According to this paper's findings, the board members' intellectual capital has no significant effect on companies' value creation and growth listed on the Tehran Stock Exchange. Given that, the board members' intellectual capital (in terms of diversity in backgrounds and educational level) is not effective to the Iranian capital market. Therefore, firstly, it should be noted to the Tehran Stock Exchange investors that the intellectual capital of the board members of listed companies in the stock exchange is neutral and has no effect on wealth creation. Secondly, we recommend the Tehran Stock Exchange's stock marketers establish policies to maintain and increase competitiveness among the listed companies, which appropriately run the board's intellectual capital. Thirdly, since today's prosperity depends on managing the intellectual capital, we recommend the required actions to possess such assets.

According to this study's findings, gender diversity has no significant effect on companies' value creation and growth listed on the Tehran Stock Exchange. So we recommend to the board of listed companies that female director appointments should not be dependent on the company's performance and growth, and other factors are also involved in this issue.

The findings of such an investigation contribute to the literature in some ways. For investors, it provides that the directors' board's external elements are more likely to impact the firm's performance, including the chief managers' ability and companies' competitive position. It is also obtained that appointing male or female members does not play a significant role in firms' outcomes; therefore, less concerns should be put into this regard. Overall findings suggest that in developing countries, intellectual capital is not taken into account by individuals. In contrast, other factors such as political connection and industry leadership may provide a better outcome for companies.

According to our findings, future researchers can investigate the other aspects of managerial characteristics, such as ability, risk-taking, independence, and ownership, on companies' accounting and market returns, which are not fully considered in developing countries. 
Future researchers may explore other potential aspects of firm performance. For example, based on our findings, education and gender diversity are not playing a determinant part in firm performance, and board members' background and professional experience might be allocative. Therefore, proceeding investigations may answer the fundamental question of which managerial characteristic is more important; education or experience?

The main limitation of this paper is excluding listed companies on out of Tehran stock exchange because of data unavailability, considering data of those companies may alter our findings. Also, the quality and ranking of universities that board members have studied in are among the important factors contributing to individual performance. The authors were not able to control for such a variable due to data unavailability.

Author Contributions: Conceptualization, M.S. and G.Z.; methodology M.S.; software, M.S.; validation, G.Z.; formal analysis, M.S.; investigation, M.S. resources, M.S. and G.Z.; data curation, M.S.; writing-original draft preparation, M.S.; writing-review and editing, G.Z.; visualization, G.Z.; supervision, M.S.; project administration, M.S. All authors have read and agreed to the published version of the manuscript.

Funding: This research received no external funding.

Institutional Review Board Statement: Not applicable.

Informed Consent Statement: Not applicable.

Data Availability Statement: Data will be available on request.

Conflicts of Interest: The authors declare no conflict of interest.

\section{References}

1. Bchini, B. Intellectual Capital and Value Creation in the Tunisian Manufacturing Companies. Procedia Econ. Financ. 2015, 23, 783-791. [CrossRef]

2. Todericiu, R.; Stăniţ, A. Intellectual Capital—The Key for Sustainable Competitive Advantage for the SME's Sector. Procedia Econ. Financ. 2015, 27, 676-681. [CrossRef]

3. Zari, A.D. Competitive Advantage and Its Sources in an Evolving Market. 2009. Available online: https://aip.scitation.org/doi/ abs/10.1063/1.3225468 (accessed on 12 June 2021).

4. Bøhren, Q.; Staubo, S. Mandatory gender balance and board independence. Eur. Financ. Manag. 2016, 22, 3-30. [CrossRef]

5. Das, S.R.; Hanouna, P.; Sarin, A. Accounting-based versus market-based cross-sectional models of CDS spreads. J. Bank. Financ. 2009, 33, 719-730. [CrossRef]

6. Díaz-Fernández, M.C.; González-Rodríguez, M.R.; Simonetti, B. Top management team's intellectual capital and firm performance. Eur. Manag. J. 2015, 33, 322-331. [CrossRef]

7. Al-Musali, M.A.K.M.; Ku Ismail, K.N.I. Board diversity and intellectual capital performance: The moderating role of the effectiveness of board meetings. Account. Res. J. 2015, 28, 268-283. [CrossRef]

8. Nielsen, S.; Huse, M. Women directors' contribution to board decision-making and strategic involvement: The role of equality perception. Eur. Manag. Rev. 2010, 7, 16-29. [CrossRef]

9. Jackson, S.E.; Joshi, A.; Erhardt, N.L. Recent research on team and organizational diversity: SWOT analysis and implications. J. Manag. 2003, 29, 801-830.

10. Moradi, M.; Salehi, M. A Study of Relationship between Board Characteristics and Earning Management: Iranian Scenario. Univers. J. Manag. Soc. Sci. 2012, 2, 12-29. Available online: https:/ / profdoc.um.ac.ir/paper-abstract-1026612.html (accessed on 10 March 2012).

11. Pham, N.; Oh, K.; Pech, R. Mergers and acquisitions: CEO duality, operating performance and stock returns in Vietnam. Pac. Basin Financ. J. 2015, 35, 298-316. [CrossRef]

12. Carter, D.A.; D'Souza, F.; Simkins, B.J.; Simpson, W.G. The Gender and Ethnic Diversity of US Boards and Board Committees and Firm Financial Performance. Corp. Gov. Int. Rev. 2010, 18, 396-414. [CrossRef]

13. Carter, D.A.; Simkins, B.J.; Simpson, W.G. Corporate Governance, Board Diversity, and Firm Value. Financ. Rev. 2003, 38 , 33-53. [CrossRef]

14. Rose, C. Does female board representation influence firm performance? The Danish evidence. Corp. Gov. Int. Rev. 2007, 15, 404-413. [CrossRef]

15. Salehi, M.; Sadatifar, Z.; Adibian, M.S. The impact of the characteristics and behaviors of the board of directors on agency costs in Iran. Contad. Adm. 2019, 66, 229. [CrossRef]

16. Cruz Basso, L.F.; Kimura, H.; De Aguiar, J.F. Intellectual capital and value creation in the production and assembly of vehicles and auto-parts sector in Brazil: A Panel data analysis. J. Mod. Account. Audit. 2010, 6, 15-25. 
17. Cabrita, M.D.R.; Jorge, L.V. Intellectual capital and value creation: Evidence from the Portuguese banking industry. Electron. J. Knowl. Manag. 2005, 4, 11-20.

18. La Torre, M.; Dumay, J.; Rea, M. Breaching intellectual capital: Critical reflections on Big Data security. Meditari Account. Res. 2018, 26, 463-482. [CrossRef]

19. Cenciarelli, V.G.; Greco, G.; Allegrini, M. Does intellectual capital help predict bankruptcy? J. Intellect. Cap. 2018, 19, $321-337$. [CrossRef]

20. Salehi, M.; Daemi, A.; Akbari, F. The effect of managerial ability on product market competition and corporate investment decisions: Evidence from Iran. J. Islam. Account. Bus. Res. 2020, 11, 49-69. [CrossRef]

21. Alcaniz, L.; Gomez-Bezares, F.; Ugarte, J.V. Firm characteristics and intellectual capital disclosure in IPO prospectuses. Acad. Rev. Latinoam. Adm. 2015, 28, 461-483. [CrossRef]

22. Zeghal, D.; Maaloul, A. Analysing value-added as an indicator of intellectual capital and its consequences on company performance. J. Intellect. Cap. 2010, 11, 39-60. [CrossRef]

23. Clarke, M.; Seng, D.; Whiting, R.H. Intellectual capital and firm performance in Australia. J. Intellect. Cap. 2011, 12, 505-530. [CrossRef]

24. Dzenopoljac, V.; Janošević, S.; Bontis, N. Intellectual capital and financial performance in the Serbian ICT industry. J. Intellect. Cap. 2016, 17, 373-396. [CrossRef]

25. Beaver, W.H.; McNichols, M.F.; Rhie, J.-W. Have Financial Statements Become Less Informative? Evidence from the Ability of Financial Ratios to Predict Bankruptcy. Rev. Account. Stud. 2005, 10, 93-122. [CrossRef]

26. Lev, B.; Gu, F. The End of Accounting and the Path forward for Investors and Managers; Wiley Finance: Hoboken, NJ, USA, 2016; ISBN 9781119191094. Available online: https:/ / onlinelibrary.wiley.com/doi/book/10.1002/978111927004 (accessed on 14 June 2016).

27. Vomberg, A.; Homburg, C.; Bornemann, T. Talented people and strong brands: The contribution of human capital and brand equity to firm value. Strat. Manag. J. 2015, 36, 2122-2131. [CrossRef]

28. Lu, Y.; Zhang, M. Effects of CEO Education Background on Firm Performance. J. Tsinghua Univ. 2015. Available online: https:/ / en.cnki.com.cn/Article_en/CJFDTotal-QHXB201504010.htm (accessed on 12 June 2021).

29. Chang, W.S.; Hsier, J.J. Intellectual capital and value creation-Is innovation capital a missing link? Int. Bus. Manag. 2011, 6, 3-12. [CrossRef]

30. Harjoto, M.A.; Laksmana, I.; Yang, Y.W. Board nationality and educational background diversity and corporate social performance. Corp. Gov. Int. J. Bus. Soc. 2019, 19, 217-239. [CrossRef]

31. Salehi, M.; Tahervafaei, M.; Tarighi, H. The effect of characteristics of audit committee and board on corporate profitability in Iran. J. Econ. Adm. Sci. 2018, 34, 71-88. [CrossRef]

32. Salehi, M.; Farzaneh, M. The impact of board's human capital on the relationship between board's characteristics and firm's performance in Iran. Int. J. Learn. Intellect. Cap. 2018, 15, 293-308. [CrossRef]

33. Polsiri, P.; Sitthipongpanich, T. CEO Characteristics and Firm Value. NIDA Dev. J. 2014, 54, 57-90.

34. Beattie, V.; Smith, S.J. Value creation and business models: Refocusing the intellectual capital debate. Br. Account. Rev. 2013, 45, 243-254. [CrossRef]

35. del Carmen Triana, M.; Orlando, C.R.; Weichieh, S. Gender diversity in senior management, strategic change, and firm performance: Examining the mediating nature of strategic change in high tech firms. Res. Policy 2019, 48, 1681-1693. [CrossRef]

36. Olayinka, E.; Jonah, A.; Lucky, O.; Vincent, O. Board Financial Education and Firm Performance: Evidence from the Healthcare Sector in Nigeria. Acad. Strateg. Manag. J. 2019, 18, 1-14.

37. Altuwaijri, B.M.; Kalyanaraman, L. CEO Education-Performance Relationship: Evidence from Saudi Arabia. J. Asian Financ. Econ. Bus. 2020, 7, 259-268. [CrossRef]

38. Saidu, S. CEO characteristics and firm performance: Focus on origin, education and ownership. J. Glob. Entrep. Res. 2019, 9, 29. [CrossRef]

39. Naseem, M.A.; Lin, J.; Rehman, R.U.; Ahmad, M.I.; Ali, R. Does capital structure mediate the link between CEO characteristics and firm performance? Manag. Decis. 2020, 58, 164-181. [CrossRef]

40. Dashtbayaz, M.L.; Salehi, M.; Mirzaei, A.; Nazaridavaji, H. The impact of corporate governance on intellectual capitals efficiency in Iran. Int. J. Islam. Middle East. Financ. Manag. 2020, 13, 749-766. [CrossRef]

41. Schmidt, I.M. Board Gender Diversity and Firm Performance: How do Educational Levels and Board Gender Quotas Affect This Relationship? Evidence from Europe (Dissertation). 2019. Available online: https://www.semanticscholar.org/paper/BoardGender-Diversity-and-Firm-performance\%3A-How-do-Schmidt/3464e468967b97bb72ebed479e5d5d5897d3d50e?p2df (accessed on 15 February 2019).

42. Elmagrhi, M.H.; Ntim, C.; Elamer, A.; Zhang, Q. A study of environmental policies and regulations, governance structures, and environmental performance: The role of female directors. Bus. Strat. Environ. 2019, 28, 206-220. [CrossRef]

43. Magoutas, A.I.; Papadogonas, T.A.; Sfakianakis, G. Market structure, education and growth. Int. J. Bus. Soc. Sci. $2012,3,12$.

44. Darmadi, S. Board members' education and firm performance: Evidence from a developing economy. Int. J. Commer. Manag. 2013, 23, 113-135. [CrossRef]

45. Doms, M.; Lewis, E.; Robb, A. Local labor force education, new business characteristics, and firm performance. J. Urban Econ. 2010, 67, 61-77. [CrossRef] 
46. Storey, D.J. Education, training and development policies and practices in medium-sized companies in the UK: Do they really influence firm performance? Omega 2002, 30, 249-264. [CrossRef]

47. Solimene, S.; Coluccia, D.; Fontana, S. Gender diversity on corporate boards: An empirical investigation of Italian listed companies. Palgrave Commun. 2017, 3, 1-7. [CrossRef]

48. Bennouri, M.; Chtioui, T.; Nagati, H.; Nekhili, M. Female board directorship and firm performance: What really matters? J. Bank. Financ. 2018, 88, 267-291. [CrossRef]

49. Hillman, A.J.; Dalziel, T. Board of directors and firm performance: Integrating agency and resource dependence perspectives. Acad. Manag. Rev. 2003, 28, 383-396. [CrossRef]

50. Adams, R.B.; Ferreira, D. Women in the boardroom and their impact on governance and performance. J. Financ. Econ. 2009, 94, 291-309. [CrossRef]

51. Hillman, A.J.; Shropshire, C.; Canella, A.A. Organizational predictors of women on corporate boards. Acad. Manag. 2007, 50, 941-952. [CrossRef]

52. Anderson, R.C.; Reeb, D.; Upadhyay, A.; Zhao, W. The Economics of Director Heterogeneity. Financ. Manag. 2011, 40, 5-38. [CrossRef]

53. Dalton, D.R.; Daily, C.M.; Certo, T.S.; Roengpitya, R. Meta-Analyses of Financial Performance and Equity: Fusion or Confusion? Acad. Manag. J. 2003, 46, 13-26. [CrossRef]

54. Robinson, G.; DeChant, K. Building a business case for diversity. Acad. Manag. Perspect. 1997, 11, 21-31. [CrossRef]

55. Beckman, C.M.; Haunschild, P.R. Network Learning: The Effects of Partners' Heterogeneity of Experience on Corporate Acquisitions. Adm. Sci. Q. 2002, 47, 92-124. [CrossRef]

56. Pucheta-Martínez, M.C.; Gallego-Álvarez, I. Do board characteristics drive firm performance? Int. Perspect. Rev. Manag. Sci. 2019. [CrossRef]

57. Loukil, N.; Yousfi, O.; Yerbanga, R. Does gender diversity on boards influence stock market liquidity? Empirical evidence from the French market. Corp. Gov. 2019, 19, 669-703. [CrossRef]

58. Yang, P.; Riepe, J.; Moser, K.; Pull, K.; Terjesen, S. Women directors, firm performance, and firm risk: A causal perspective. Leadersh. Q. 2019, 30, 101297. [CrossRef]

59. Green, C.P.; Homroy, S. Female directors, board committees and firm performance. Eur. Econ. Rev. 2018, 102, 19-38. [CrossRef]

60. Reguera-Alvarado, N.; De Fuentes, P.; Laffarga, J. Does board gender diversity influence financial performance? Evidence from Spain. J. Bus. Ethics 2017, 141, 337-350. [CrossRef]

61. Boerner, S.; Linkohr, M.; Kiefer, S. Top management team diversity: Positive in the short run, but negative in the long run? Team Perform. Manag. Int. J. 2011, 17, 328-353. [CrossRef]

62. Pucheta-Martínez, M.C.; Bel-Oms, I.; Olcina-Sempere, G. Female Institutional Directors on Boards and Firm Value. J. Bus. Ethics 2018, 152, 343-363. [CrossRef]

63. Ntim, C.G. Board diversity and organizational valuation: Unravelling the effects of ethnicity and gender. J. Manag. Gov. 2015, 19, 167-195. [CrossRef]

64. Aripin, N.; Hassan, N.L.; Amran, N.A.; Ismail, K.N.I.K.; Abdul-Manaf, K.B. Do Malaysian Women Directors Create Corporate Value? Adv. Sci. Lett. 2016, 22, 1423-1426. [CrossRef]

65. Mengi, T.; Bhatia, D.B. Value Creation in Indian Corporate Sector: Comparison of MVA \& EVA. Int. J. Mark. Financ. Serv. Manag. Res. 2015, 4, 2.

66. Miller, T.; Del Carmen Triana, M. Demographic Diversity in the Boardroom: Mediators of the Board Diversity-Firm Performance Relationship. J. Manag. Stud. 2009, 46, 755-786. [CrossRef]

67. Campbell, K.; Vera, A.M. Female board appointments and firm valuation: Short and long-term effects. J. Manag. Gov. 2010, 14, 37-59. [CrossRef]

68. Lock, R.; Smith, L.H. The impact of female entrepreneurship on economic growth in Kenya. Int. J. Gend. Entrep. 2016, 8, 90-96. [CrossRef]

69. Okah-Efogo, F.; Timba, G.T. Female entrepreneurship and growth in Cameroon. Afr. J. Econ. Manag. Stud. 2015, 6, 107-119. [CrossRef]

70. Reichborn-Kjennerud, K.; Svare, H. Entrepreneurial growth strategies: The female touch. Int. J. Gend. Entrep. 2014, 6, 181-199. [CrossRef]

71. Salehi, M.; Dashtbayaz, M.L.; Lotfi, A. The relationship between institutional and management own-ership and financial flexibility in Iran. Corp. Board Role Duties Compos. 2016, 12, 35-42. [CrossRef]

72. Salehi, M.; Fakhri Mahmoudi, M.R.; Daemi Gah, A. A meta-analysis approach for determinants of effective factors on audit quality: Evidence from emerging market. J. Account. Emerg. Econ. 2019, 9, 287-312. [CrossRef]

73. Amiri Farah Abadi, J.; Soleymani, S.; Abolghasemi, M. Probing Open Data Policy Making Role in Policy Optimization in Iran's Higher Education System. IQBQ 2018, 22, 103-126. 